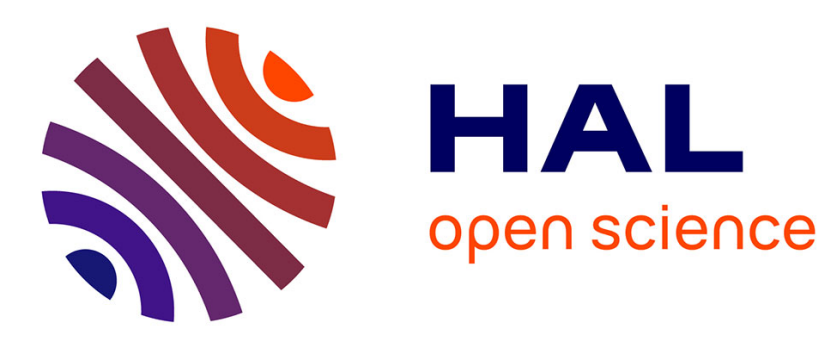

\title{
The endocannabinoid system in vertebrate male reproduction: A comparative overview
}

Giovanna Cacciola, Teresa Chioccarelli, Giulia Ricci, Rosaria Meccariello, Silvia Fasano, Riccardo Pierantoni, Gilda Cobellis

\section{To cite this version:}

Giovanna Cacciola, Teresa Chioccarelli, Giulia Ricci, Rosaria Meccariello, Silvia Fasano, et al.. The endocannabinoid system in vertebrate male reproduction: A comparative overview. Molecular and Cellular Endocrinology, 2008, 286 (1-2), 10.1016/j.mce.2008.01.004 • hal-00531981

\section{HAL Id: hal-00531981 \\ https://hal.science/hal-00531981}

Submitted on 4 Nov 2010

HAL is a multi-disciplinary open access archive for the deposit and dissemination of scientific research documents, whether they are published or not. The documents may come from teaching and research institutions in France or abroad, or from public or private research centers.
L'archive ouverte pluridisciplinaire HAL, est destinée au dépôt et à la diffusion de documents scientifiques de niveau recherche, publiés ou non, émanant des établissements d'enseignement et de recherche français ou étrangers, des laboratoires publics ou privés. 


\section{Accepted Manuscript}

Title: The endocannabinoid system in vertebrate male reproduction: A comparative overview

Authors: Giovanna Cacciola, Teresa Chioccarelli, Giulia Ricci, Rosaria Meccariello, Silvia Fasano, Riccardo Pierantoni, Gilda Cobellis

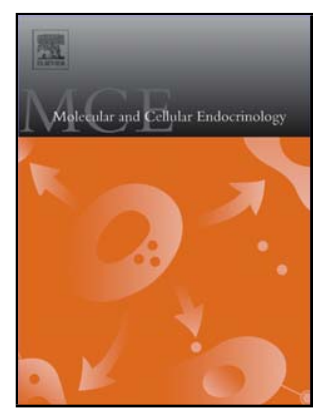

PII: S0303-7207(08)00010-5

DOI: doi:10.1016/j.mce.2008.01.004

Reference: MCE 6788

To appear in: $\quad$ Molecular and Cellular Endocrinology

Received date: $\quad 14-12-2007$

Revised date: $\quad 11-1-2008$

Accepted date: $\quad 11-1-2008$

Please cite this article as: Cacciola, G., Chioccarelli, T., Ricci, G., Meccariello, R., Fasano, S., Pierantoni, R., Cobellis, G., The endocannabinoid system in vertebrate male reproduction: A comparative overview, Molecular and Cellular Endocrinology (2007), doi:10.1016/j.mce.2008.01.004

This is a PDF file of an unedited manuscript that has been accepted for publication. As a service to our customers we are providing this early version of the manuscript. The manuscript will undergo copyediting, typesetting, and review of the resulting proof before it is published in its final form. Please note that during the production process errors may be discovered which could affect the content, and all legal disclaimers that apply to the journal pertain. 


\title{
The endocannabinoid system in vertebrate male reproduction: a comparative overview
}

Giovanna Cacciola ${ }^{1}$, Teresa Chioccarelli ${ }^{1}$, Giulia Ricci ${ }^{2}$, Rosaria Meccariello ${ }^{3}$, Silvia Fasano ${ }^{1}$, Riccardo Pierantoni ${ }^{1}$, Gilda Cobellis ${ }^{1}{ }^{*}$

${ }^{1}$ Dipartimento di Medicina Sperimentale, Sez. "F. Bottazzi”, II Università degli Studi di Napoli, Via Costantinopoli 16, 80138 Napoli, Italia

${ }^{2}$ Dipartimento di Medicina Sperimentale, Sez. "F. Bottazzi”, Laboratorio di Istologia, II Università degli Studi di Napoli, Via Costantinopili 16, 80138 Napoli, Italia

${ }^{3}$ Dipartimento di Studi delle Istituzioni e dei Sistemi Territoriali, Università degli Studi di Napoli Parthenope, Via Medina 40, 80133 Napoli, Italia

* Corresponding Author

\begin{abstract}
Prevailing studies emphasize on endocannabinoid activity in brain. However, sporadic evidences hint that endocannabinoid system controls male reproduction ranging from invertebrates to vertebrates. Although $\mathrm{N}$-arachidonoylethanolamine is described in rat testis, its activity is still poorly known. Type-1 cannabinoid receptor and fatty acid amide hydrolase are particularly expressed in elongating spermatids and spermatozoa suggesting that endocannabinoids affect spermiogenesis and sperm physiology. Aim of this paper is to provide an analysis of the information available in vertebrates on male germ cell progression and sperm maturation mediated by the endocannabinoid system.
\end{abstract}

\section{Content}

1. Endocannabinoid system.

2. Endocannabinoid system and spermatogenesis.

3. Endocannabioid system and acquisition of sperm motility

4. Concluding remarks

\section{Endocannabinoid system}

Endogenous cannabinoids (endocannabinoids) are an emerging class of lipid mediators isolated from brain (Devane et al., 1992), peripheral tissues (Sugiura et al., 2002) and reproductive fluids (Schuel et al., 2002) with psychotropic, hypnotic and analgesic effects matching cannabinoids 
(Ledent et al., 1999). To date, at least four brain-derived compounds have been identified and designed as endocannabinoids (Devane et al., 1992; Sugiura et al., 2002; Stella et al., 1997; Hanus et al., 2001; Porter et al., 2002): arachidonoylethanolamide, (AEA or anandamide), 2-arachidonylglycerol (2-AG), 2-arachidonyl-glyceryl ether and virodhamine. Furthermore, several additional lipid mediators, such as N-oleoylethanolamine (OEA) and N-palmitoylethanolamine (PEA), are now considered endocannabinoid-like molecules or entourage compounds being able to improve the activity of AEA and 2-AG by inhibiting their degradation (Ben-Shabat et al., 1998; Lambert and Di Marzo 1999; De Petrocellis et al., 2004). AEA and 2-AG are the endocannabinoids whose biological activity has been better characterized (Pertwee and Ross, 2002; Hillard et al., 2003). They bind to extracellular site of the G-protein coupled type-1 and type-2 cannabinoid receptors (CB1 and CB2) (Matsuda et al., 1990; Munro et al., 1993) matching some effects of $\mathrm{D}^{9}$ tetrahydrocannabinol (THC), the primary psycho-active component of marijuana (Howlett et al., 2002). These two compounds have different affinities for CB1 and CB2, being AEA more selective for the former and 2-AG equally potent and efficacious at both binding sites (Howlett et al., 2002). Unlike 2-AG, AEA also acts on intracellular sites of ion channels such as those of the transient receptor potential vanilloid type 1 (TRPV1 or VR1) protein (also activated by the pungent compound of hot chilli pepper, capsaicin) and the T-type calcium channels (van der Stelt et al., 2005). The effects of AEA and 2-AG, via $\mathrm{CB} 1$ and $\mathrm{CB} 2$ receptors, depend on their concentration in the extracellular space which is controlled by: i) $\mathrm{Ca}^{2+}$-dependent biosynthesis occurring on demand by membrane precursors and requiring the sequential action of specific enzymes [e.g Nacyltransferase (NAT)( Hansen et al., 2000) and N-acylphosphatidylethanol-amine (NAPE)-specific phospholipase-D (PLD) for AEA (Okamoto et al., 2004), and phosphatidic acid phosphohydrolase or phosphoinositide-selective phospholipase C (PI-PLC) as well as sn-1-diacylglicerol lipase (DAGL) for 2-AG (Stella et al., 1997)]; ii) cellular uptake requiring a hypothesized endocannabinoid membrane transporter (EMT) (Beltramo and Piomelli 2000) and iii) intracellular degradation requiring fatty acid amide hydrolyse (FAAH), to degrade both AEA and 2-AG, as well as monoacylglycerol lipase (MAGL), to degrade specifically 2-AG (Dinh et al., 2002; Ho et al., 2002).

Altogether, endocannabinoids, receptors, transporter, enzymes for their synthesis and degradation constitute the "endocannabinoid system" (Beltramo et al., 1997; Hillard et al., 1997; Di Marzo et al., 1999; Pertwee et al., 2002).

\section{Endocannabinoid system and spermatogenesis}


It is now well established that cannabinoids/endocannabinoids influence the male reproductive function (Maccarrone et al., 2002; Brown and Dobs 2002). Cannabinoids inhibit spermatogenesis, reduce the weight of reproductive organs, and also production, motility and viability of sperm cells (Kolodny et al., 1974). Furthermore, they regulate testosterone production by Leydig cells both in vivo and in vitro (Dalterio et al., 1983) and cause impotency in male rat (Murphy et al., 1994). Endocannabinoids are synthesised by gonads. Rat testis produces AEA (Sugiura et al., 1996). Feasible testicular AEA sources are Sertoli and germ cells since isolated mammalian immature Sertoli cells (Maccarrone et al., 2003) and mammalian and non mammalian spermatozoa (SPZ) (Maccarrone et al., 2005; Cobellis et al., 2006) produce endocannabinoids. The presence of AEA in the testis suggests that endocannabinoids are implicated in spermatogenesis and/or steroidogenesis. Accordingly, orthologues of $\mathrm{CB}$ receptors and FAAH have been evidenced in testis of the invertebrate, Ciona intestinalis (Matias et al., 2005), CB receptors have been localized in germinal compartment cells of mammalian male gonad (Gye et al., 2005), and CB1-knockout (CB1-KO) mice show low secretion of testicular testosterone in in vitro study (Wenger et al., 2001). However, few data exist to establish physiology of endocannabinoids in testicular activity.

Spermatogenesis is a process highly conserved throughout vertebrate species (Perantoni et al., 2002; Cobellis et al., 2003). Thus, committed spermatogonia (SPG) develop in spermatocytes (SPCs) and enter meiosis to produce spermatids (SPTs). These undergo a morphological transformation (spermiogenesis) into mature elongated SPT (also indicated as SPZ) which are differentially released from Sertoli cells (spermiation) depending on the species. Therefore, spermatogenesis involves mitosis, meiosis and differentiation events in spermiogenesis. These events are driven by gonadotropin and by a network of local signals whose presence is suggested by testicular morphology (Pierantoni et al., 2002; Cobellis et al., 2003). In mammals, two compartments are distinguishable in the testis: 1) the vascularized interstitial compartment (O'Donnel et al 2001; Pierantoni et al., 2002), with steroidogenic Leydig cells, producing androgens, mainly testosterone (fibroblasts and macrophages are also present) and 2) the tubular compartment constituted by outer peritubular cells and by Sertoli cells surrounding and nursing germ cells at different developmental stages (Russell LD 1998). The association between Sertoli cells and a specific set of germ cells changes along the tubule and identify the single stages (I-XIV in rat) of spermatogenesis (Leblond and Clermont 1955). This complex testicular organization, as well as the presence of local communications, makes difficult to approach mammalian spermatogenesis through in vivo and in vitro study. The use of experimental animal models different from mammals, as well as that of knock out (KO) mice, has given the opportunity to study local cell-to-cell communications and factors involved in endocrine control mechanisms directly in vivo. Indeed, non mammalian 
vertebrate models show anatomical organizations that allow access to tissues not readily approachable in mammals. Thus, the testicular zonation in elasmobranches (Fig. 1A) (Pratt 1988; Pierantoni and Fasano 1991), or the compartimentalization in urodeles (Fig. 1B) (Lofts 1987; Pierantoni et al., 2002), as well as the cyclic regeneration of the interstitium, including differentiating Leydig cells, in the reptile, Podarcis s. sicula (Andò et al., 1990), may facilitate analysis of signals promoting differentiation of testicular cells. The anuran amphibian, the frog Rana esculenta, represents a powerful tool to easily delineate the molecular signalling implicated in the control of spermatogenesis (Pierantoni et al., 2002a; Pierantoni et al,. 2002b; Cobellis et al., 2003). Spermatogenesis occurs in cysts consisting of Sertoli cells enveloping clusters of germ cells at a synchronous stage (Fig. 1C) (Rastogi et al., 1976). During the annual sexual cycle new cysts monthly appear and progress throughout spermatogenesis stages depending on endocrine and local events (Pierantoni et al., 2002b). This conveys the considerable advantage to have in each period of the year a defined and well known population of germ cysts. As a consequence, during the year, when in February-March period spermatogenesis resumes and SPG proliferate, the cystic organization of spermatogenesis progressively enriches the testis of clusters of SPC (May-June) followed by SPT appearance (September-October) and SPZ, retained in the tubules until March, when spermiation and sperm release occur (Rastogi et al., 1976).

Using a comparative approach, we have recently evidenced CB1 and FAAH in the testis of frogs (Cobellis et al., 2006) and rats (Cacciola G., Chioccarelli T., Mackie K., Meccariello R., Fasano S., Pierantoni R., Cobellis G., unpublished). Data confirm and/or extend previous studies carried out in mice demonstrating the presence of FAAH in isolated immature Sertoli cells (Maccarrone et al., 2003) and CB1 in Leydig (Wenger et al.2001; Gye et al., 2005) and germ cells (from spermatogonia to SPZ) (Gye et al., 2005). In frogs (Cobellis et al., 2006), the expression profile of CB1 and FAAH during the annual sexual cycle (Fig. 2) shows higher levels of both proteins in September-October period, when the cystic organization of spermatogenesis enriches testis of a massive number of elongating (e) SPT and newly formed SPZ. Immunocytochemistry (ICC) shows a weak CB1 signal in SPG and SPC and a more intense signal in elongating SPT and SPZ. The same kind of immunolocalization is observed for FAAH in SPC, SPT and SPZ. In rats, ICC localizes CB1 in interstitial and tubular compartments (Cacciola G., Chioccarelli T., Mackie K., Meccariello R., Fasano S., Pierantoni R., Cobellis G., unpublished) and in particular in Leydig cells, in Sertoli cells and in round (r) SPT during their differentiation in SPZ. In rSPT the signal is concentrated around the nucleus where acrosome is. Signal is retained in eSPT and, in particular, in the head, always near the acrosome region. The same kind of immunolocalization is observed for FAAH in rSPT and eSPT. In addition, FAAH is also expressed in SPC and in Leydig cells. The 
localization of CB1 and FAAH in eSPT (Fig 3) suggests the involvement of the endocannabinoid system in spermiogenesis (probably in acrosome and cellular shape configuration) and also hints that FAAH, controlling endocannabinoid levels, establishes the endocannabinoid tone needed for a right morphology of these cells. Accordingly, marijuana smokers show morphological alterations of SPZ (Hembree et al., 1978; Issidorides 1978). Localization of CB1 in Sertoli cells, here reported, does not agree with data obtained by Maccarrone et al. (2003). However, results can be reconciled. In fact, it is well know that functional activity of Sertoli cells depends on the associated germ cell stages. Maccarrone used immature Sertoli cells from 4-16 dpp old mice. Since at that time only SPG and SPC are present in the testis while more mature stages of germ cells are almost absent (Bellvé et al., 1977), it is possible to postulate that CB1 switches on in Sertoli cells later in development to support mature germ cells (from rSPT to SPZ). Accordingly, in adult rat, CB1 stained Sertoli cells appear in stages with elongating SPT (Cacciola G., Chioccarelli T., Mackie K., Meccariello R., Fasano S., Pierantoni R., Cobellis G., unpublished). The immunolocalization of CB1 in the testis during the first wave of spermatogenesis could reveal when CB1 appears in Sertoli cells. Further experiments should be carried out in this respect.

\section{Endocannabinoid system and acquisition of sperm motility}

After spermatogenesis, the mature SPT are released from Sertoli cells into the tubule lumen (spermiation) and proceed through the excurrent duct system, differentially organized according to the species (Pierantoni 1998; Birkhead 1998; Le Gac and Lair 1998; Johnson et al., 1998). In amphibians (Fig.4A), we observe a simple excurrent duct system with several efferent ducts, leaving testis and entering only one external duct (properly indicated as spermatic duct) which confluences in cloaca. In mammals (Fig.4B), a more complex excurrent duct system, where sperm maturation occurs, is present; it includes: rete testis, efferent ducts, epididymus, vas deferens, ejaculatory duct and a segment of the urethra. Some of the main events of sperm maturation (i.e membrane remodelling, motility acquisition, chromatin condensation and the movement of cytoplasmic droplet from the neck to the head of mid piece) occur in the epididymus (Redman 1998).

Recently, it has been shown that endocannabinoids are present in amphibian cloacal fluid (Cobellis et al., 2006) and in human seminal plasma (Schuel et al., 2002), suggesting that endocannabinoids may influence important steps controlling sperm maturation or function (Wang et al., 2006). Consistently, a complete endocannabinoid system has been characterized in boar SPZ. These cells produce AEA and express TRPV1, FAAH, CB2 and CB1 (Maccarrone et al., 2005). CB1 has also been evidenced in human sperm (Rossato et al., 2005) while in frog, rat (Cobellis et al., 2006) and 
boar (Maccarrone et al., 2005) SPZ, both CB1 and FAAH have been detected. Immunofluorescence demonstrates that CB1 is present in the head and tail of human (Rossato et al., 2005), boar (Maccarrone et al., 2005) and rat SPZ (Cacciola G., Chioccarelli T., Mackie K., Meccariello R., Fasano S., Pierantoni R., Cobellis G., unpublished). Unlike boar, where CB1 is localized in postacrosomal region, in rats the confocal analysis shows the protein near the acrosome. Altogether these findings support the observation concerning the endocanabinoid influence on acrosome reaction ( Schuel et al., 2002; Maccarrone et al., 2005; Schuel et al., 2005) and sperm motility (Rossato et al. 2005; Cobellis et al., 2006) through CB1.

In vitro studies show that AEA inhibits motility of human (Rossato et al., 2005) and frog SPZ (Cobellis et al., 2006). In particular, the inhibitory effect on frog SPZ is mediated by CB1 (as in humans) and is counteracted by sperm washing (Fig. 5A) or dilution (Fig. 5B); furthermore, motility is counteracted by $\mathrm{CB1}$ antagonist in cloacal fluid (Fig. 5C), suggesting that endocannabinoids control the number of motile SPZ, via CB1, keeping sperm motility quiescent until their release in aquatic environment (“dilution mechanism"). Since the endocannabinoid system has been demonstrated to be highly conserved in evolution (Matias et al., 2005), the new perspective coming from the above described data is that, besides frogs, a change of CB1 receptor activity and/or endocannabinoid levels might control sperm motility acquisition also in mammals along the epididymus from the caput to the cauda (Ricci et al., 2007). In mammals, the mechanism of sperm motility acquisition, needed for fertilization, is a two step mechanism: 1) the former occurs in the epididymus; 2) the latter occurs in the female reproductive tract. In fact, after spermiation, immotile SPZ reach the epididymus by passive transport and here, moving from caput to cauda, acquire motility (Cobellis et al., 2005 and references there in). The phenotype analysis of wild type (WT) and CB1-KO male mice (Ricci et al., 2007) demonstrates that endocannabinoid/CB1 signalling affects sperm motility in the epididymus. Indeed, lack of CB1 clearly increases the percentage of motile SPZ in caput which becomes comparable to that observed in the cauda. These results let to hypothesise that CB1 signalling control number of motile SPZ along the epididymus (low in caput and high in cauda) keeping quiescent sperm motility in the caput.

\section{Concluding remarks}

Male reproduction requires a network of endocrine, paracrine as well as autocrine mechanisms and comparative studies indicate that highly conserved processes are active among phylogenetically distant species. 
Data here reported suggest that the endocannabinoid system regulates male reproduction from $C$. intestinalis to mammals. Moreover, sperm motility acquisition mechanism seems to be conserved in both amphibians and mammals. Indeed, endocannabinoids play a central inhibitory role in either animal systems but, of course, they adapt actions depending on the environment. In amphibians, where external (aquatic) fertilization occurs, a "dilution mechanism" evolved to enhance sperm motility; in mammals, living in the terrestrial environment, a mechanism generated into epididymus and involving CB1 activity is generated to trigger sperm motility in cauda.

\section{Legends}

Fig. 1 (a) Testis of the dogfish, Scyliorhinus canicula, showing the typical zonation. A, ampullogenic zone containing unit made up of one spermatogonium and Sertoli cells; B, zone containing ampullae with spermatocytes; $\mathrm{C}$, zone containing ampullae with early stage spermatids; $\mathrm{D}$, zone containing ampullae with latest stage spermatids and spermatozoa. (b) Schematic representation of cephalocaudal zonation in the urodele amphibian testis. (c) Hematoxylin-eosin stain showing testicular section of Rana esculenta. The cystic organization of spermatogenesis is schematically depicted in the inset. n: Sertoli cell nucleus.

Fig. 2 (A) Western blot analysis showing testicular expression of CB1, FAAH and MAPK1 during the annual reproductive cycle of Rana esculenta. (B) CB1/MAPK1 values are expressed in optical density (OD) units and graphed. (C) FAAH/MAPK1 values are expressed in optical dentisity (OD) units and graphed.

Fig. 3 Immunocytochemistry for CB1 or FAAH presence in Rana esculenta (A-B) and rat (C-D) testis. Scale bar: $10 \mu \mathrm{m}$.

Fig. 4 (A) Amphibian urogenital system. (B) Mammalian urogenital system.

Fig. 5 (A) Effects of AEA on motility of frog SPZ. SPZ, collected in their fluid from the cloacae, were diluted (1:5) in physiological solution and incubated in absence or presence of $\mathrm{AEA} \pm \mathrm{SR} 141716 \mathrm{~A}$. SPZ motility was also evaluated in washed SPZ after AEA treatment. (B) Effects of dilution of cloacal fluid on number of motile SPZ. (C) Effects of the selective CB1 antagonist (SR141716A) on number of motile SPZ in cloacal fluid. Sperm viability was not affected by treatments. 


\section{References}

Andò S., Panno M.L., Garcia G., Imbrogno E., Buffone M., Beraldi E., Sischi D., Angelici F., Botte V. 1990. Plasma sex hormone concentrations durino the reproductive cycle in the lizard Podarcis s. sicula. J. Reprod. Fertil. 90, 353-360.

Beltramo M., Stella N., Malignano A., Lin S.Y., Makriyannis A., Piomelli D. 1997. Functional role of high-affinity anandamide transport as revealed by selective inhibition. Science 277, 1094-1097.

Beltramo M., Piomelli D. 2000. Carrier-mediated transport and enzymatic hydrolysis of the endogenous cannabinoid 2-Arachidonoyl-glycerol. Neurorep. 11, 1231-1235.

Bellvé A.R., Caricchia J.C., Milette C.F., O’Brien D.A., Bhatnagar Y.M., Dym M. 1977. Spermatogenic cells of the prepuberal mouse. Isolation and morphologycal characterization. $\mathrm{J}$ Cell. Biol. 74, 68-85.

Ben-Shabat S., Fride E., Sheskin T., Tamiri T., Rhee M.H., Vogel Z., Bisogno T., De Petrocellis L., Di Marzo V., Mechoulam R. 1998. An entourage effect : inactive endogenous fatty acid glycerol esters enhance 2-arachidonoyl-glycerol cannabinoidi activity. Eur. J. Pharmacol. 353, 23-31.

Birkhead T. M.1998. Male reproductive system, birds. In: Encyclopedia of Reproduction 3, pp. 15-19. Knobil- Neill Eds.

Brown T.T., Dobs A.S. 2002. Endocrine effects of marijuana. J Clin Pharmacol. 42, 90S-96S.

Chang M.C., Berkery D., Schuel R., Laychock S., Zimmerman A.M., Zimmerman S., Schuel H. 1993. Evidence for a cannabinoid receptor in sea urchin sperm and its role in blockade of the acrosome reaction. Mol. Reprod. Dev. 36. 507-516.

Cobellis G., Cacciola G., Scarpa D., Meccariello R., Chianese R., Franzoni M.F., Mackie K., Pierantoni R., Fasano S. 2006. Endocannabinoid system in frog and rodent testis: type-1 cannabinoid receptor and fatty acid amide hydrolase activity in male germ cells. Biol. Reprod. 75, 82-89.

Cobellis G., Lombardi M., Scarpa D., Izzo G., Fienga G., Meccariello R., Pierantoni R., Fasano S. 2005. Fra1 activity in the frog, Rana esculenta, testis: a new potential role in sperm transport. Biol. Reprod. 72, 1101-1108.

Cobellis G., Meccariello R., Fienga G., Pierantoni R., Fasano S. 2002. Cytoplasmic and nuclear Fos protein forms regulate resumption of spermatogenesis in the frog, Rana esculenta. Endocrinology. 143,163-170.

Cobellis G., Meccariello R., Pierantoni R., Fasano S. 2003. Intratesticular signals for progression of germ cell stages in vertebrates. Gen. Comp. Endocrinol., 134:220-228.

Dalterio S.L., Bartke A., Mayfield D.L. 1983. Cannabinoids stimulate and inhibit testosterone production in vitro and in vivo. Life Science 32, 605-612.

De Petrocellis L., Cascio M.G., Di Marzo V. 2004. The endocannabinoid system: a general view and latest additions. Br. J. Pharmacol. 141, 765-774. 
Devane W.A., Hannus L., Breuer A., Pertwee R.G., Stevenson L.A., Griffin G., Gibson D., Mandelbaum A., Etinger A., Mechoulam R. 1992. Isolation and structure of a brain constituent that binds to the cannabinoid receptor. Science 258, 1946-1949.

Di Marzo V., Bisogno T., De Petrocellis L., Melck D., Orlando P., Wagner J.A., Kunos G. 1999. Biosynthesis and inactivation of the endocannabinoid 2-arachidoylglycerol in circulating and tumoral macrophages. Eur. J. Biochem. 264, 258-267.

Dinh T.P., Carpenter D., Leslie F.M., Freund T.F., Katona I., Sensi S.L., Kathuria S., Piomelli D. 2002 Brain monoglyceride lipase participating in endocannabinoid inactivation. Proc. Natl. Acad. Sci. USA 99, 10819-10824.

Gye M.C., Kang H.H., Kang H.J. 2005. Expression of cannabinoid receptor type-1 in mouse testes. Arch. Androl. 51, 247-255.

Hansen H.H., Hansen S.H., Schousboe A., Hansen H.S. 2000. Determination of the fospholipid precursor of anandamide and other $\mathrm{N}$-acylethaanolamine phospholipids before and after sodium azide- induced toxicity in cultured neocortical neurons. J. Neurochem. 75, 861-871.

Hanus L., Abu-Lafi S., Fride E., Breuer A., Vogel Z., Shalev D.E., Kustanovic I., Mechoulam R. 2001. 2-Arachidonoyl-glyceril ether, an endogenus agonist of the cannabinoid CB1 receptor. Proc. Nat. Aca. Sci. USA. 98, 3662-3665.

Hembree $3^{\text {rd }}$ W.C., Nahas G.G., Zeidemberg P, Huang H.F. 1978. Changes in human spermatozoa associated with high dose marihjuana smoking. Adv. Biosci 22-23, 429-439.

Hillard C.J., Edgemond W.S., Jarrahian A., Campbell W. 1997. Accumulation of Narachidono-ylethanolamine (anandamide) into cerebellar granule cells occurs via facilitated diffusion. J. Neurochem. 69, 631-638.

Hillard C.J., Jarrahian A. 2003. Cellular accumulation of anandamide: consensus and controversy. Br. J. Pharm. 140, 802-808.

Ho S.Y., Delgado L., Storch J. 2002. Monoacilglycerol metabolism in human intestinal Caco-2 cells: evidence for metabolic compartmentation and hydrolysis. J. Biol. Chem. 277, 1816-1823.

Howlett A.C., Barth F., Bonner T.I., Cabral G., Casellas P., Devane W.A., Felder C.C., Herkenham M., Mackie K., Martin B.R., Mechoulam R., Pertwee R.G. 2002. International Union of Pharmacology XXVII Classification of cannabinoid receptors. Pharmacol. Rev. 54, 161-202.

Issidorides M.R. 1978. Observations in cronic hashish users: nuclear aberrations in blood and sperm and abnormal acrosomes in spermatozoa. Adv. Biosci. 22-23, 377-388.

Johnson L., Falk G.U., Spoede G.E. 1998. Male reproductive system, non human mammals. In: Encyclopedia of Reproduction 3, pp. 49-60. Knobil- Neill Eds.

Kolodny R.C., Master W.H., Kolodner R.M., Toro G. 1974. Depression of plasma testosterone levels after chronic intensive marihuana use. N. Engl. J. Med. 290, 872-874. 
Lambert D.M., Di Marzo V. 1999. The palmitoyethanolamide and oleamide enigmas: are these two fatty acid amides cannabimimetic? Curr. Med. Chem. 6, 757-773.

Leblond C.P. and Clermont Y. 1955. Definition of the stages of the cycle of the seminiferous epithelium in the rat. Ann. New York Accad. Sci. 55, 548-573.

Ledent C., Valverde O., Cossu G., Petitet F., Albert J.F., Baslet F., Bohrne G.A., Imperato A., Pedrazzini T., Roques B.P., Vasart G., Fratta W., Parmentier M. 1999. Unresponsiveness to cannabinoids and reduced additive effects of opiates in CB1 receptor Knock out mice. Science 283, 401-404.

Le Gac F. and Loir M. 1998. Male reproductive system, fish. In: Encyclopedia of Reproduction 3, pp. 20-30. Knobil- Neill Eds.

Lofts B. 1987. Testicular function. In " Hormones and reproduction in fishes, amphibians and reptiles” 283-326. Plenum press New York.

Maccarrone M., Barboni B., Paradisi A., Bernabò N., Gasperi V., Pistilli M.G., Fezza F., Lucidi P., Mattioli M. 2005. Characterization of the endocannabinoid system in boar spermatozoa and implications for sperm capacitation and acrosome reaction. J Cell Sci 118, 4393-4404.

Maccarrone M., Cecconi S., Rossi G., Battista N., Pauselli R., Finazzi-Agrò A. 2003. Anandamide activity and degradation are regulated by early postnatal aging and folliclestimulating hormone in mouse Sertoli cells. Endocrinology 144, 20-28.

Maccarrone M., Falciglia K., Di Rienzo M., Finazzi-Agrò A. 2002. Endocannabinoids, hormone-cytokine networks and human fertility. Prost. Leukot. Essent. Fatty Acids 66, 309317.

Matias I., McPartland J.M., Di Marzo V. 2005. Occurrence and possible biological role of the endocannabinoid system in the sea squirt Ciona intestinalis. J. Neurochem. 93,1141-56.

Matsuda L.A., Lolait S.J., Brownstein M.J., Young A.C., Bonner T.I. 1990. Structure of a cannabinoid receptor and functional expression of the cloned cDNA. Nature 346, 561-564.

Munro S., Thomas K.L., Abu-Shaar M. 1993. Molecular characterization of a peripheral receptor for cannabinoids. Nature 365, 61-65.

Murphy L.L., Gher J., Steger R.W., Bartker A. 1994. Effects of delta 9-tetrahydrocannabinol on copulatory behavior and neuroendocrine responses of male rats to female conspecifics. Pharmacol. Biochem. Behav. 48, 1011-1017.

O'Donnell L., Robertson K.M., Jones M.E., Simpson E.R. 2001. Estrogen and spermatogenesis. Endocr. Rev. 22, 289-318.

Okamoto Y., Morishita J., Tsuboi K., Tonai T., Ueda N. 2004. Molecular characterization of phospholipase D generating anandamide and its congeners. J. Biol. Chem. 279, 5298-5305. 
Pertwee R.G., Ross R.A., Craib S.J., Thomas A. 2002. (-)- Cannabidiol antagonizes cannabinoidi receptor agonists and noradrenaline in the mouse vas deferens. Eur. J. Pharmacol. 456 (1-3), 99-106.

Pertwee R.G. and Ross R.A. 2002. Cannabinoid receptors and their ligands. Prost. Leukot. Essent. Fatty Acids 66,101-121.

Pierantoni R., Cobellis G., Meccariello R., Fasano S. 2002. Evolutionary aspects of cellular communication in the vertebrate hypothalamo-hypophysio-gonadal axis. Int. Rev. Cytol. 218, 69-141.

Pierantoni R., Cobellis G., Meccariello R., Palmiero C., Fienga G., Minucci S., Fasano S. 2002. The amphibian testis as model to study germ cell progression during spermatogenesis. Comp. Biochem. Physiol. Biochem. Mol. Biol. 132,131-9.

Pierantoni R. 1998. Male reproductive system, amphibians. In: Encyclopedia of Reproduction 3, pp. 10-15. Knobil- Neill Eds.

Pierantoni R., Fasano S. 1991. Functional morphology and regulation of the hypothalamus hypophysis-gonadal axis: a comparative overview. In "Form and function in Zoology", 225243. Mucchi Modena.

Porter A.C., Sauer J.M., Knierman M.D., Becker G.W., Berna M.J., Bao J., Nomikos G.G., Carter P., Bymaster F.P., Leese A.B., Felder C.C. 2002. Characterization of a novel endocannabinoid, virodhamine, with antagonist activity at the CB1 receptor. J. Pharmacol. Exp. Ther. 301, 10201024.

Pratt H.L. jr 1998. Elasmobranch gonad structure: a description and survey. Copeia 3, 719-729.

Rastogi R.K., Iela L., Saxena P.K., Chieffi G. 1976. The control of spermatogenesis in the green frog, Rana esculenta J. Exp. Zool. 169,151-166.

Redman J.F. 1998. Male reproductive system, human. In: Encyclopedia of Reproduction 3, pp. 30-41. Knobil- Neill Eds.

Ricci G., Cacciola G., Altucci L., Meccariello R., Pierantoni R., Fasano S., Cobellis G. 2007. Endocannabinoid control of sperm motility: the role of epididymus. Gen. Comp. Endoc. 153(13), 320-322.

Rossato M., Popa F.I., Ferigo M., Clari G., Foresta C. 2005. Human sperm express cannabinoid receptor CNR1, the activation of which inhibits motility, acrosome reaction and mitochondrial function. J. Clin. Endocrinol. Metab. 90, 984-991.

Schuel H., Burkman L.J., Lippes J., Crickard K., Forester E., Piomelli D., Giuffrida A. 2002. N-Acylethanolamines in human reproductive fluids. Chem. Phys. Lipids 121, 211-227.

Schuel H. and Burkman L.J. 2005. A tale of two cells: endocannabinoid-signalling regulates functions of neurons and sperm. Biol. Reprod. 73,1078-1086. 
Schuel H., Burkman L.J., Lippes J., Crickard K., Mahony M.C., Giuffrida A., Picone R.P., Makriyannis A. 2002. Evidence that anandamide-signalling regulates human sperm functions required for fertilization. Mol. Reprod. Dev. 63, 376-387.

Schuel H., Goldstein E., Mechoulam R., Zimmerman A.M., Zimmerman S. 1994. Anandamide (arachidonylethanolamide), a brain cannabinoid receptor agonist, reduces sperm fertilizing capacity in sea urchins by inhibiting the acrosome reaction. Proc Natl Acad Sci USA 91, 76787682.

Stella N., Schweitzer P., and Piomelli D. 1997. A second endogenous cannabinoid that modulates long-term potentiation. Nature 388, 773-778.

Sugiura T., Kobayashi Y., Oka S., Waku K. 2002. Biosynthesis and degradation of anandamide and 2-arachidonoylglycerol and their possible physiological significance. Prostaglandins and Leukot Essent. Fatty Acid. 66, 173-192.

Sugiura T., Kondo S., Sukagawa A., Tonegawa T., Nakane S., Yamashita A., Waku K. 1996. Enzymatic synthesis of anandamide, an endogenous cannabinoid receptor ligand, through Nacylphosphatidylethanolamine pathway in the testis: involvement of $\mathrm{Ca} 2+$-dependent transacylase and phosphodiesterase activities. Biochem. Biophys. Res. Comm. 218,113-117.

Van der Stelt M., Di Marzo V. 2005. Anandamide as an intracellular messenger regulating ion channel activity. Prost. Other Lipid Mediat. 77,111-122.

Wang H., Dey S.K., Maccarrone M. 2006. Jekyll and hyde: two faces of cannabinoid signaling in male and female fertility. Endocr. Rev. 27, 427-448.

Wenger T., Ledent C., Csernus V., Gerendai I. 2001. The central cannabinoid receptor inactivation suppresses endocrine reproductive functions. Biochem. Biophys. Res. Commun. 284, 363-368. 
a)

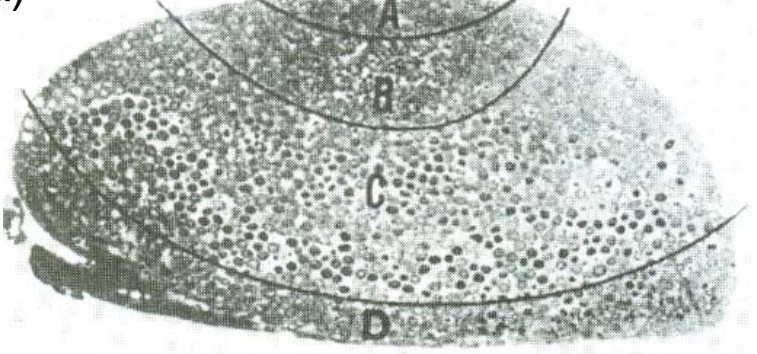

c)

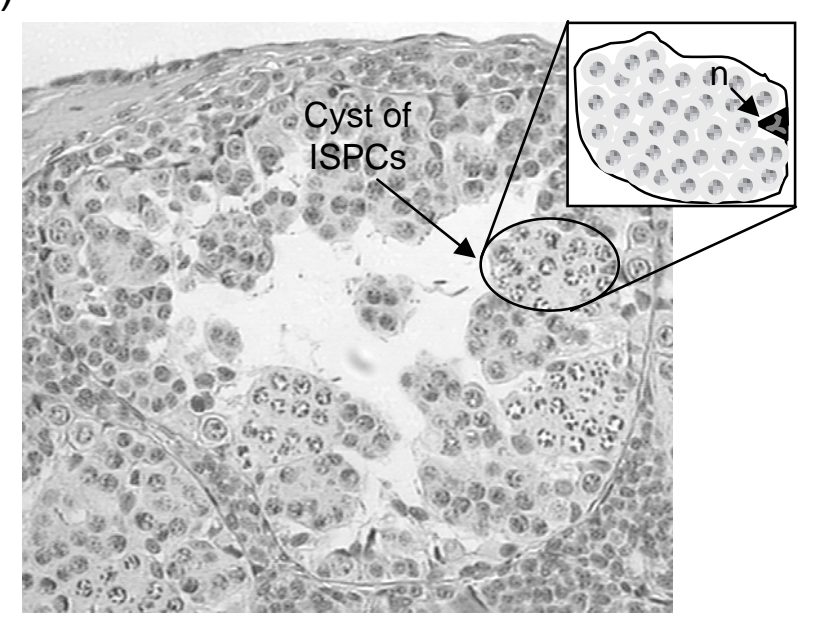

b)

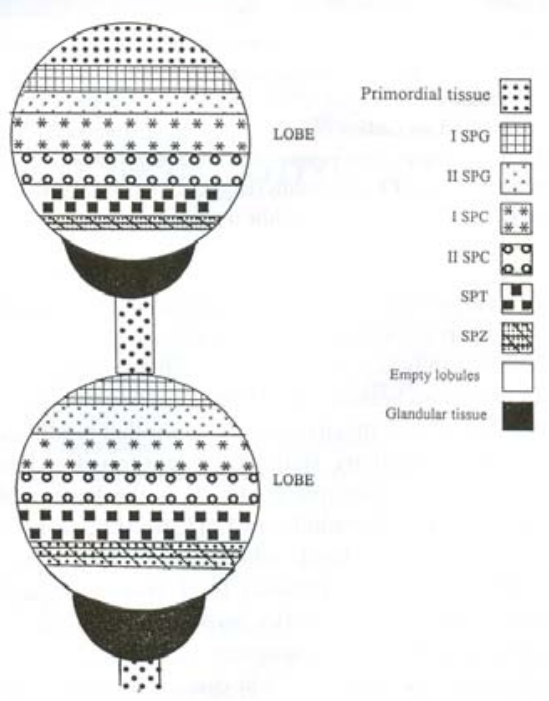


A)

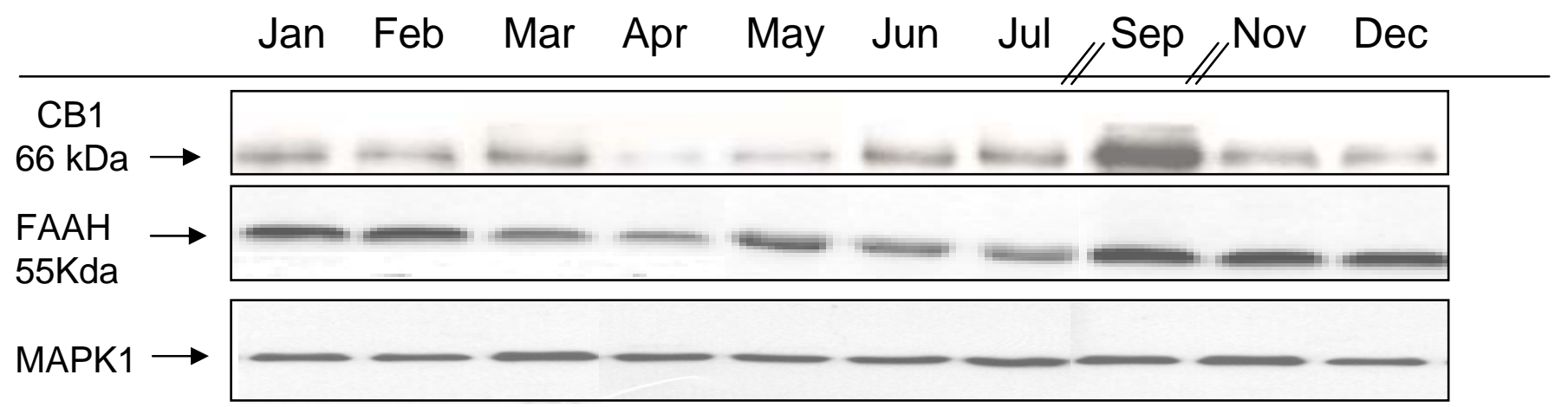

B)
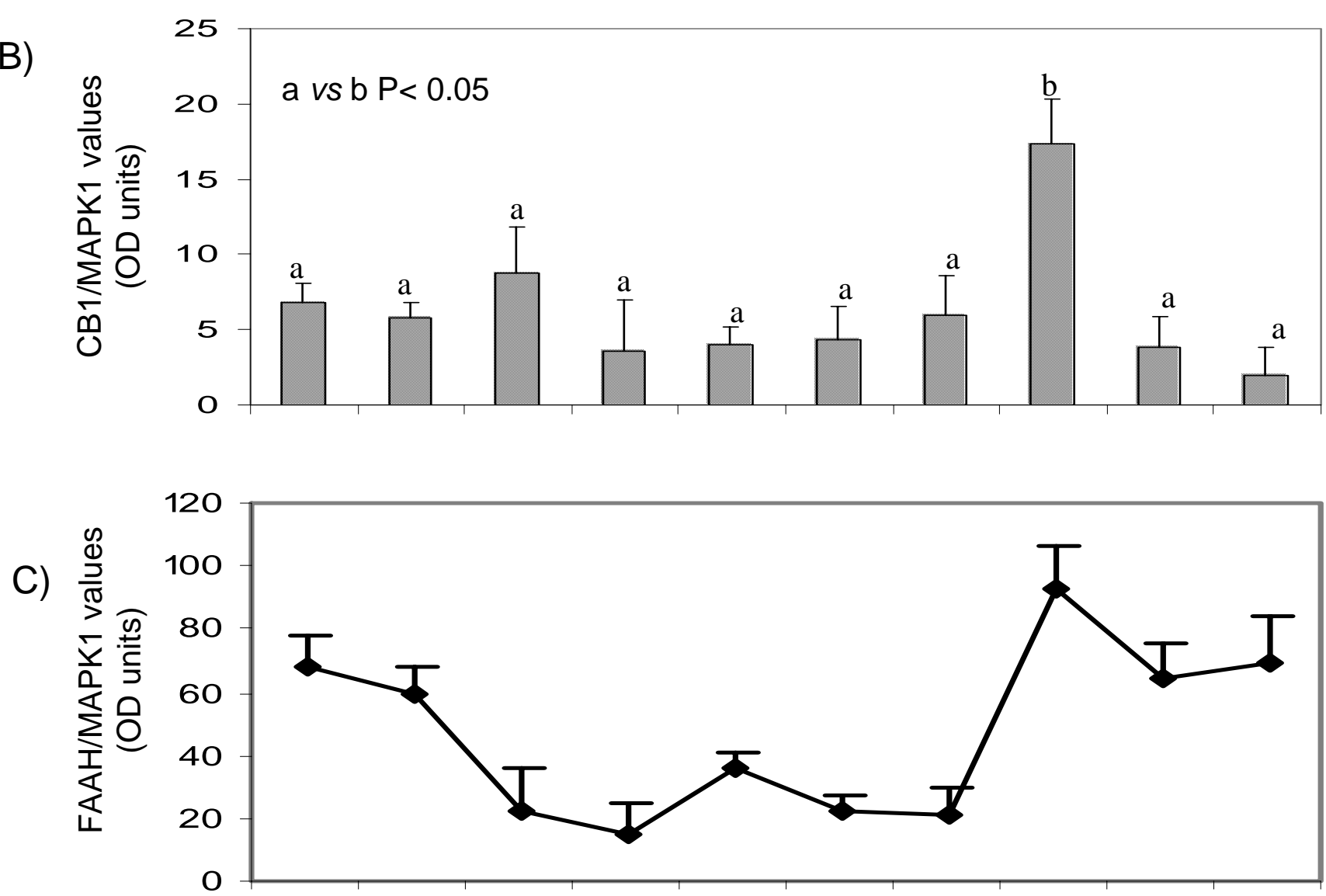


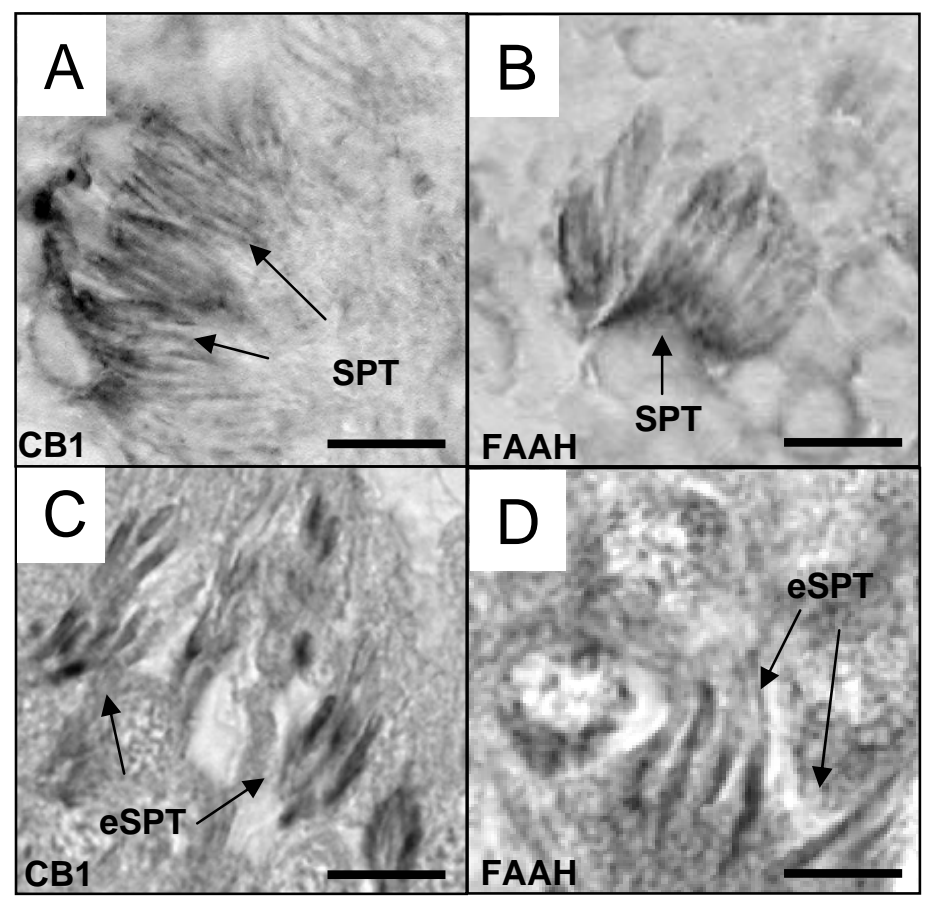



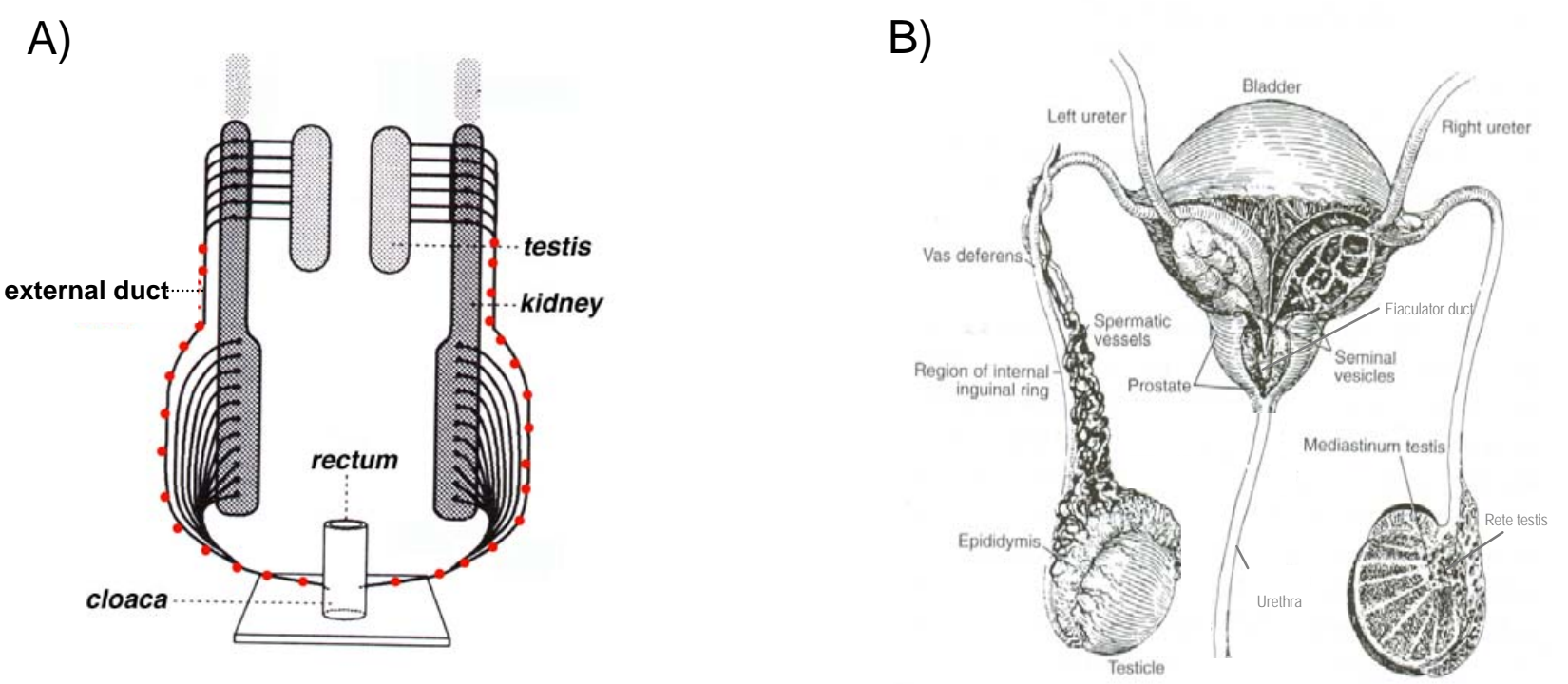

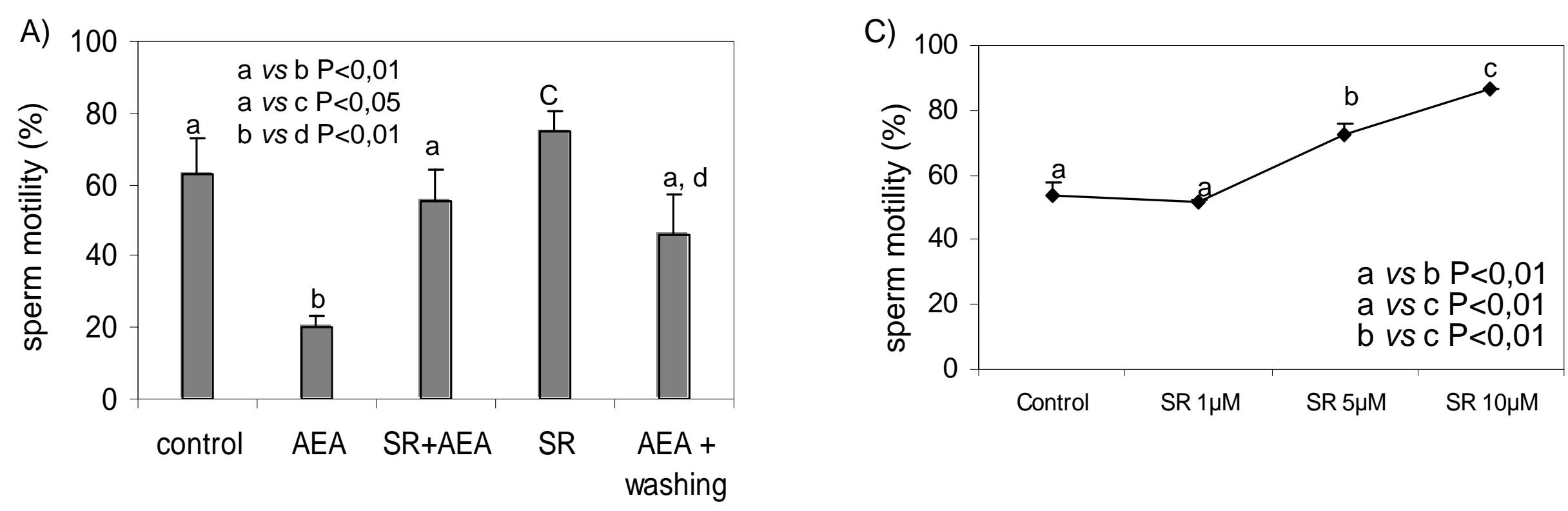

B)

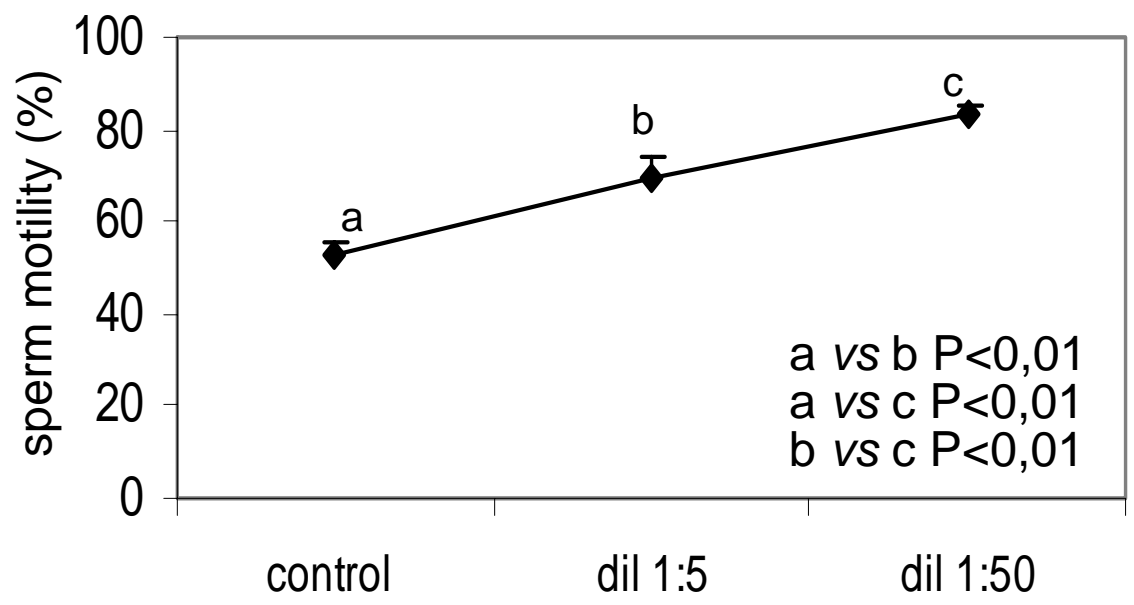

